\title{
DEFAULT IN OF LEGAL AID COLLABORATION AGREEMENT BETWEEN ADVOCATES AND REGIONAL GOVERNMENTS OF CENTRAL BENGKULU REGENCY
}

By:

Febricka Riezky Ramadhanti, Ganefi, Candra Irawan

\begin{abstract}
This study aimed to determine and analyze the implementation of the cooperation contract between the Regional Government of Central Bengkulu Regency and advocates in the field of providing legal aid and to find out and analyze the settlement in the event of a dispute in the implementation of a cooperation contract between the Regional Government of Bengkulu Tengah Regency and an advocates in the field of providing legal aid. This research was an empirical research and the data analysis used was qualitative with deductive-inductive thinking method. The results showed that the cooperation contract between the Regional Government of Bengkulu Tengah Regency and advocates in the field of providing legal assistance was carried out through a written agreement. The legal basis for the cooperation contract was based on Article 9 letter $a$ and $b$ of Law Number 16 of 2011 concerning Legal Aid, specifically stipulated by the Decree of the Regent of Central Bengkulu Number 3 of 2013 concerning the Stipulation of Advocates/Lawyers in the Context of Resolving Legal Problems for Civil Servants/Apparatus in the Regional Government of Central Bengkulu Regency in 2013 and all costs in the implementation of the cooperation contract for the provision of legal assistance were borne by the Regional Government of Central Bengkulu Regency through Number DPA 1.20 (1.20.03) .20.09.5.2. Whereas the obstacles in implementing the cooperation contract between the Regional Government of Central Bengkulu Regency and advocates in the field of providing legal assistance included the payment of honorariums to lawyers who were often late or paid once every three months, as a result lawyers could not carry out their duties and functions properly. The settlement of these obstacles by both parties agreed to do non-litigation, which was negotiations, so that the cooperation agreement would not be broken.
\end{abstract}

Key Words: Default, Cooperation Agreement, Advocate Legal Aid, Regional Government of Central Bengkulu Regency. 


\section{A. INTRODUCTION}

\section{Research Background}

The State of Indonesia is a rule of law, this is explicitly stated in the 1945 Constitution of the Republic of Indonesia. The principles of a rule of law state include, among other things, the guarantee of equality for everyone before the law (equality before the law), including people or group of the poor who have not been reached by justice so far. Legal issues that ensnare many individuals, groups or legal issues at the government level.

According to Akhmad Muslih, a rule of law state is "a state that is run based on the principle of legality and the principle of protection of basic rights for every human being as well as protection of the general welfare".

Based on the results of preresearch in Central Bengkulu Regency, information was obtained from Zohri Kusnadi as Head of the Legal Department of the Regional Government Secretariat of Central

\footnotetext{
Akhmad Muslih, 2011, Kedudukan Peraturan Kebijakan Dalam Peraturan PerundangUndangan Kajian Khusus Peraturan Kebijakan (Beleidsregel) Kompilasi Hukum Islam, Cipta Grafika, Jakarta. Pg. 185.
}

Bengkulu that, ${ }^{2}$ Central Bengkulu Regency is one of the districts in Bengkulu Province that has used the services of legal practitioners in overcoming legal problems in the Regency Government of Central Bengkulu. The implementation of this legal aid contract is regulated in the Regional Regulation of the Central Bengkulu Regency Number 1 of 2008 concerning the Organizational Structure and Work Procedure of the Regional Apparatus of Central Bengkulu Regency, so in implementing government activities it was certain that it was related to legal issues, the Regional Government of Central Bengkulu Regency established cooperation with advocates through a cooperation contract agreement Number: $\quad$ 001/PKS/B.2/2018 and Number: 01/VN.30.8/LAB-HKM/2018 between the Central Bengkulu Regency Government represented by Muzakir Hamidi as the Regional Secretary of Central Bengkulu Regency with the Advocate ,Tri Andika regarding Case Study and Legal Aid for the Regional

2 Zohri Kusnadi as Head of the Legal Department of the Regional Government Secretariat of Central Bengkulu, interviewed on 13 ${ }^{\text {th }}$ of Agustus 2018. 
Government of Bengkulu Tengah

Regency.

In the implementation of the legal aid cooperation agreement between the Central Bengkulu Regency Government and advocates, there were problems or obstacles, including payment to advocates; Tri Andika, Helmi Sudanda and Emi Herawati, often being late or being held for three months after the trial, while the agreement stated in the provisions of Article 3 of Obligations Parties, First Party verse (1) and (2) stated that

Verse (1) states:

Providing services for every civil case and PTUN (State Administrative Procedure Law) where the payment of services is calculated at every trial to the Second Party.

Verse (2) states:

Bear the cost of action as referred to in Article 1 letter $\mathrm{d}^{3}$ of this cooperation contract

${ }^{3}$ Article 1 letter $\mathrm{d}$ of the Cooperation Contract Agreement states: Action costs are all costs incurred as a result of carrying out legal actions, both litigation and non-litigation by advocates, can be administrative in nature, warning / subpoena, lobbying, accommodation, transportation or operational costs. -Other official fees, the amount of which is seen and adjusted for each case requirement and available budget agreement for every action taken by the Second Party.

Based on the background description above, the writer was interested in further examining it in a thesis entitled: "Default of the Legal Aid Cooperation Agreement between Advocates and the Regional Government of Central Bengkulu Regency".

\section{Problem Identification}

Based on the background description above, the problems were:

a. Why was there a default in the implementation of the legal aid cooperation agreement between advocates and the Regional Government of Central Bengkulu Regency?

b. How was the settlement of defaults in agreement of the legal aid cooperation between advocates and the Regional Government of Central Bengkulu Regency?

\section{B. RESEARCH METHODOLOGY}

This type of research was empirical legal research. Empirical juridical legal research is legal research 
conducted by examining data directly in the field to obtain primary data. ${ }^{4}$ Empirical legal research is legal research conducted by examining data directly in the field (community) to obtain primary data. Ronny Hanitijo Soemitro, stated that juridical sociological/empirical legal research is "legal research that obtains primary and secondary data". 5

Population is the whole object or individual or symptom under study, ${ }^{6}$ so the population in this study was the Regional Government of Central Bengkulu Regency and advocates. The samples in this study were: 1) Head of the Legal Department of the Regional Secretariat of Central Bengkulu Regency; 2) Head of Subdivision. Legal Aid and Legal Counseling of the Regional Secretariat of Central Bengkulu Regency; 3) 3 (three) Advocates, namely Tri Adika, Helmi Suanda and Emi Herawati and 5 (three) legal aid recipients. Data

${ }^{4}$ Soerjono Soekanto dan Sri Mamudji, 2002, Penelitian Hukum Normatif, Rajawali Pers, Jakarta. Pg 14-15.

${ }^{5}$ Ronny Hanitijo Soemitro, 1994, Metode Penelitian Hukum dan Jurimetri, Ghalia Indonesia, Jakarta, Pg. 52.

${ }^{6}$ Bambang Sunggono, 1996, Metode Penelitian Hukum, Raja Grafindo Persada, Jakarta. Pg.121. analysis used qualitative juridical analysis, which was data analysis that was not a calculation and test of numbers, but using words with a deductive method and inductive method.

\section{RESULTS AND DISCUSSION}

1. Implementation of Default of Legal Aid Cooperation Agreement between Advocates and Regional Government of Central Bengkulu Regency

Based on the results of the preresearch in Central Bengkulu Regency, information was obtained from Zohri Kusnadi as Head of the Legal Department of Regional Government Secretariat of the Central Bengkulu ${ }^{7}$ that the cooperation contract within the Regional Government has been clearly regulated as stated in Government Regulation Number 50 of 2007 concerning Procedures for Implementing Regional Cooperation, based on Article 3 letter $\mathrm{d}$. Government Regulation Number 50 of 2007 has determined that the subject of cooperation was between the regional

${ }^{7}$ Zohri Kusnadi as Head of Legal Division of Regional Government Secretariat of the Central Bengkulu, interviewed on August 13 $3^{\text {th }}, 2018$. 
head and a third party. Whereas the object of cooperation between regional heads and third parties was all government affairs that have become the authority of an autonomous region and could be in the form of providing public services (here it was interpreted that one of them was the provision of legal assistance), this cooperation was contained in the regional cooperation contract where the third party, which was the intention of the third party, was the Non-Departmental Government Ministries/Institutions or other names, private companies with legal status, State-Owned Enterprises, Regional-Owned Enterprises, Cooperatives, Foundations, and other domestic institutions that are legal entities.

In the Decree of Regent of Central Bengkulu Number 3 of 2013, stipulates 3 (three) Advocates/Lawyers who provided legal assistance in the context of solving legal problems for civil servants/apparatus in the Regional Government of Central Bengkulu Regency, with advocates, they were:
a. Tri Andika
b. Helmi Suanda
c. Emi Herawati

The implementation of the cooperation contract between the Regional Government of Central Bengkulu Regency and advocates in the field of providing legal assistance was borne by the Regional Budget of Central Bengkulu Regency through the Regional Work Unit Budget Implementation Document (DPA$S K P D)$ of the Legal Administration Section of the Regional Secretariat of Central Bengkulu Regency at coordinating and fostering legal issues for civil servants/apparatus in the Regional Government of Central Bengkulu Regency with Number DPA 1.20 (1.20.03) 20.09.5.2. Provision of legal assistance was for the Regional Government of Central Bengkulu Regency and the poor in Central Bengkulu Regency.

Based on the results of interviews with Tri Andika, Helmi Suanda, and Emi Herawati, ${ }^{8}$ as advocates, information was obtained that the procedure or method of providing legal assistance to the poor in Central Bengkulu, was submitted by

\footnotetext{
8 Tri Andika, Helmi Suanda, and Emi Herawati, Advocates Providing Legal Aid in the Regional Government of Central Bengkulu Regency, interviewed March 24 $4^{\text {th }}, 2020$.
} 
the applicant for legal aid, by submitting a written request for Legal Aid to the Regent of Central Bengkulu.

The cooperation contract between the Regional Government of Central Bengkulu Regency and advocates in the field of providing legal assistance was carried out through a written agreement. The legal basis for the cooperation contract was based on Article 9 letters $a$ and $b$ of Law Number 16 of 2011 concerning Legal Aid, specifically stipulated by the Decree of the Regent of Central Bengkulu Number 3 of 2013 concerning the Stipulation of Advocates/Lawyers in the Context of Resolving Legal Problems for Civil Servants/ Apparatus in the Regional Government of Central Bengkulu Regency in 2013. All costs in implementing the cooperation contract between the Regional Government of Central Bengkulu Regency and advocates in the field of providing legal assistance were borne by the Regional Budget of Central Bengkulu Regency through the Regional Work Unit Budget Implementation Document (DPA-SKPD) of Legal Division of the Regional Secretariat of
Central Bengkulu Regency in the coordination and development of civil servants/apparatus legal issues in the Regional Government of Central Bengkulu Regency with Number DPA 1.20 (1.20.03) 20.09.5.2 with barriers of late payment or being paid every three months.

According to Helmi Suanda, in reality, lawyers get paycheck on a regular basis every three months. Of course this became an obstacle in the implementation of providing legal aid because there were no operational advocates to carry out their obligations. If the avocado asked for operational funds from clients, this certainly violated contracts and laws and regulations. This situation was certainly a dilemma, Bengkulu Province could not be equated with other big cities in Indonesia. In big cities, especially Jakarta, the profession of an advocate is a good thing and guarantees the economic life of lawyers. Bengkulu Province is a small city, so the paycheck from the Regional Government of Central Bengkulu Regency plays an important role in implementing legal aid for lawyers. 
According to Emi Herawati, that if the advocates did not carry out their obligations, then the advocates would be declared to have neglected their obligations and have violated the contract. If it was reviewed based on the contract, the Regional Government of Central Bengkulu Regency which has neglected its obligation to pay fees for advocates on a regular basis could be stated to be one of the causes of the non-progress of the legal aid process for clients.

$$
\text { Based on the results of }
$$
interviews with Tri Andika, Helmi Suada, and Emi Herawati, as Advocates for Legal Aid Providers in the Bengkulu Regency Government, it was obtained information that the target for case resolution was not achieved, due to the two remaining cases whose trials were often postponed by the Bengkulu District Court.

\section{Settlement of Defaults in the} Legal Aid Cooperation Agreement between Advocates and the Regional Government of

\section{Central Bengkulu Regency}

Based on the results of preresearch in CentralBengkulu Regency, information was obtained from Zohri Kusnadi as Head of the Legal Department of the Regional Government Secretariat of Central Bengkulu. ${ }^{9}$ That the obstacles in the implementation of cooperation contracts that have the potential for disputes between each party were due to the budget system where the budget realization process required a fairly long grace period, in this case the Legal Administration Section of the Secretariat of the Republic of Indonesia. Central Bengkulu conducted negotiations with advocates and tried to pay part of the advocates' fees by first borrowing money from the expenditure treasurer at the General Administration Section of the Regional Secretariat of Central Bengkulu until the disbursement of activity money to pay off advocate fees.

According to the results of preresearch in Bengkulu Tengah Regency, information was obtained from Zohri Kusnadi as Head of the Legal Department of the Bengkulu Tengah

${ }^{9}$ Zohri Kusnadi as Head of Legal Division of the Bengkulu Tengah Regional Government Secretariat, interviewed on August $13^{\text {th }}, 2018$. 
Regional Government Secretariat. ${ }^{10}$ That following up on reports of legal aid recipients who provided money in the form of transportation, accommodation for advocates because when the violation approached the end of the fiscal year, the cooperation contract with advocates would continue for the next fiscal year. The government of Central Bengkulu Regency would terminate the contract with the lawyer directly and enter into a contract with the institution for easy supervision. In addition, the Regional Government of Central Bengkulu Regency, in this case the Legal Administration Section of the Regional Secretariat of Central Bengkulu Regency, did not yet have a legal basis in the form of Regional Regulations and Regent Regulations concerning Requirements and Procedures for Providing Legal Aid as guidelines for implementation in the regions and it was hoped that in the future this could be formulated.

\section{CLOSING}

\section{Conclusion}

${ }^{10}$ Zohri Kusnadi as Head of Legal Division of the Bengkulu Tengah Regional Government Secretariat, interviewed on August 13 ${ }^{\text {th }}, 2018$.
Based on the description in the discussion, the following conclusions could be drawn as follows:

a. The default of the cooperation contract between the Regional Government of Central Bengkulu Regency and advocates in the field of providing legal assistance was carried out through a written agreement. The legal basis for the cooperation contract was based on Article 9 letters $\mathrm{a}$ and $\mathrm{b}$ of Law Number 16 of 2011 concerning Legal Aid, specifically stipulated by Decree of the Regent of Central Bengkulu Number 3 of 2013 concerning the Appointment of Advocates/Lawyers in the Context of Resolving Legal Problems of Civil Servants/ Apparatus at the Regional Government of Central Bengkulu Regency in 2013 and all costs in the implementation of the cooperation contract for the provision of legal aid were borne by the Regional Government of the Central Bengkulu Regency through Number DPA 1.20 (1.20.03) 20.09.5.2.

b. The settlement of defaults in the legal aid cooperation agreement 
between advocates and the Regional Government of Central Bengkulu Regency was carried out in non-litigation, which was negotiations, so that the cooperation agreement did not occur.

\section{Suggestion}

The government of Central Bengkulu Regency must create a special reserve fund for advocates, so that there is no delay in disbursing the advocate's honorarium. Late payment to lawyers can interfere their work process, because there are advocates who live outside Central Bengkulu Regency. For advocates, even though the payment is often late, do not reduce legal assistance for the poor or ask for money that is difficult for clients to fulfill because it is inappropriate and clients are poor people.

\section{REFERENCES}

\section{Books :}

A. Qirom Syamsuddin Meliala, 1985, Pokokpokok Hukum Perjanjian, Liberty, Yogyakarta.

Ahmadi Miru, 2007, Hukum Kontrak dan Perancangan Kontrak, Rajawali Pers, Jakarta.
Ahmadi Miru, Sakka Pati, 2008, Hukum Perikatan, Rajawali Pers, Jakarta.

Akhmad Muslih, 2011, Kedudukan Peraturan Kebijakan Dalam Peraturan Perundang-Undangan Kajian Khusus Peraturan Kebijakan (Beleidsregel) Kompilasi Hukum Islam, Cipta Grafika, Jakarta.

Bagir Manan, 1994, Hubungan antara Pusat dan Daerah Menurut UUD 1945, Sinar Harapan, Jakarta.

Bambang Sunggono dan Aries Harianto, 1994, Bantuan Hukum dan Hak Asasi Manusia, CV. Mandar Maju, Bandung.

Bambang Sunggono, 1996, Metode Penelitian Hukum, Raja Grafindo Persada, Jakarta.

C.S.T. Kansil, 1986, Pengantar Ilmu Hukum, Balai Pustaka, Jakarta. , 1989, Pengantar Ilmu Hukum dan Tata Hukum Indonesia, Balaipustaka, Jakarta.

Darji Darmodiharjo dan Shidarta, 2008, Pokok-Pokok Filsafat Hukum: Apa dan Bagaimana Filsafat Hukum Indonesia, Gramedia Pustaka Utama, Jakarta.

H. A. Sukris Sarmadi, 2009, Advokat; Litigasi dan Non Litigasi Pengadilan, CV. Mandar Maju, Bandung.

Ishaq, 2010, Pendidikan Keadvokatan, Sinar Grafika, Jakarta.

M. Marwan dan Jimmy P., 2009, Kamus Hukum, Reality Publisher, Surabaya. 
M. Yahya Harahap, 2002, Pembahasan Permasalahan dan Penerapan KUHAP, SinarGrafika, Jakarta.

Mortir Jedawi, 2001, Desentralisasi dan Implementasi di Indonesia, PPs Unhas, Makasar.

Nur Ihsan, 2008, Prosedur Pemberian Bantuan Hukum Dengan CumaCuma Dan Pelaksanaannya Melalui Pengadilan Negeri Bagi Terdakwa yang Tersangkut Perkara Pidana Di Pengadilan Negeri Kelas I A Padang, Fakultas Hukum Universitas Andalas, Sumatera Barat.

Nurmaningsih Amriani, 2011. Mediasi Alternatif Penyelesaian Sengketa Perdata di Pengadilan, PT. RajaGrafindo Persada, Jakarta.

Peter Mahmud Marzuki, 2009, Pengantar Ilmu Hukum. Kencana, Jakarta.

R. Subekti, R. Tjitrosoedibio, 2004, Kitab Undang-Undang Hukum Perdata, Dengan Tambahan UndangUndang Pokok Agraria, UndangUndang Perkawinan. PT. Paradya Paramita, Jakarta.

Rahmat Rosyadi dan Sri Hartini, 2003, Advokat dalam Perspektif Islam \& Hukum Positif, Ghalia Indonesia, Jakarta.

Ronny Hanitijo Soemitro, 1994, Metode Penelitian Hukum dan Jurimetri, Ghalia Indonesia, Jakarta.

Salim H.S, 2008, Perkembangan Hukum Kontrak Innominaat di Indonesia, Sinar Grafika, Jakarta.
, 2008, Pengantar Hukum Perdata Tertulis $(B W)$, Rajawali Pers, Jakarta.

Salim H.S, 2003, Hukum Kontrak Teori \& Teknik Penyusunan Kontrak, Sinar Grafika, Jakarta

Samuel Gishanah, 2011, Kontrak Kerjasama Antara Sekretariat Daerah Semarang Dalam Bidang Pemberian Bantuan Hukum, Fakultas Hukum Universitas Katolik, Semarang.

Sartono dan Bhektin Suryani, 2018, PrinsipPrinsip Dasar Profesi Advokat, Dunia Cerdas, Jakarta.

Satjipto Rahardjo, 2009, Hukum dan Perilaku Hudup Baik adalah Dasar Hukum Yang Baik, Kompas, Jakarta.

Sayifullah, 2010, Perjanjian Bantuan Hukum antara Pemeritah Daerah Yogyakarta dan Lembaga Bantuan Hukum, Fakultas Syari'ah dan Hukum Universitas Islam Negeri Sunan Kalijaga, Yogyakarta.

Sidik Sunaryo, 2004, Kapita Selekta Sistem Peradilan Pidana, Penerbitan Universitas Muhammadiyah Malang, Malang.

Siswanto Sunarno, 2008, Hukum Pemerintahan Daerah di Indonesia, Sinar Grafika, Jakarta.

Soerjono Soekanto dan Sri Mamudji, 2002, Penelitian Hukum Normatif, Rajawali Pers, Jakarta.

Soerjono Soekanto, Bantuan Hukum Suatu Jaminan Tinjauan Sosio Yuridis, Ghalia Indonesia, Jakarta. 
Soetandyo Wignjosoebroto, 2008, Hukum Dalam Masyarakat Perkembangan dan Masalah, Bayumedia Publishing, Malang.

Sri Soedewi Masyohen Sofwan, 1981, Hukum Acara Perdata Indonesia dalam Teori dan Praktek, Liberty, Yogyakarta.

Subekti, 1982, Pokok-Pokok Hukum Perdata, PT.Intermasa, Jakarta. , 2007, Kitab Undang-Undang Hukum Perdata, PT. Arga Printing, Jakarta.

\section{Regulation :}

Undang-Undang Dasar Negara Republik Indonesia Tahun 1945.

Undang-Undang Nomor 30 Tahun 1999 tentang Arbitrase dan Alternatif Penyelesaian Sengketa

Undang-Undang Nomor 16 Tahun 2011 tentang Bantuan Hukum.

Undang-Undang Nomor 23 Tahun 2014 tentang Pemerintahan Daerah.
Peraturan Daerah Kabupaten Bengkulu Tengah Nomor 1 Tahun 2008 tentang Struktur Organisasi dan Tata Kerja Perangkat Daerah Kabupaten Bengkulu Tengah.

Website :

Jimly Asshiddiqie, Penegakan hukum http://jimly.com/makalah/namafile 156/Penegakan_Hukum.pdf, diunduh 02 Okbober 2020

Kerjasama Daerah oleh Suparmono, di akses di http://www.slideshare.net/suparmo no/kerjasama-daerah2\#! tanggal 10 Januari 2020.

Muhammad Yasin, Inilah Hasil tentang Bantuan Hukum di Daerah, diakses dari http://www.hukumonline.com donlot tanggal 8 Oktober 2020 at 20:20:35 Wib.

Tujuan

Hukum, http://www.hukumsumberhukum.c om/2019/01/apakah-itu-tujuanhukum.html, diunduh 5 Oktober 2020. 